\title{
Opening history of Powell Basin, Antarctic Peninsula
}

\author{
Graeme Eagles $^{\mathrm{a}, 1}$, Roy A. Livermore ${ }^{\mathrm{b}, *}$ \\ a School of Earth Sciences, University of Leeds, Leeds LS2 9JT, UK \\ b British Antarctic Survey, High Cross, Madingley Road, Cambridge CB3 OET, UK
}

Received 5 December 2000; accepted 5 February 2002

\begin{abstract}
The opening of Powell Basin was part of the regional response to $\mathrm{N} 55^{\circ} \mathrm{W}$ relative plate motion of South America away from Antarctica, which led to the formation of Drake Passage during the Eocene and Oligocene. Restoration of microplates around the basin using gridded magnetic anomalies from its margins illustrates the pre-break-up continuity of the Pacific Margin Anomaly magnetic high associated with a Mesozoic arc-batholith. Newly compiled magnetic anomaly data over the Powell Basin show subdued linear seafloor spreading type anomalies. These are used, together with marginal and regional geology, to constrain the opening history of the basin. Magnetic reversal modelling suggests that slow spreading in Powell Basin probably occurred between $29.7 \mathrm{Ma}$ and $21.8 \mathrm{Ma}$, following rifting of Mesozoic continental crust with associated break-up volcanism. A simple, two-phase model for the rotation of the South Orkney Microcontinent away from the Antarctic Peninsula accounts for the pattern of magnetic reversals recorded in Powell Basin, and for the structure of its margins. Crown Copyright (C) 2002 Elsevier Science B.V. All rights reserved.
\end{abstract}

Keywords: Antarctic; Neogene; seafloor spreading; magnetic anomalies

\section{Introduction}

The Late Palaeogene separation of South America from the Antarctic Peninsula led to the creation of Drake Passage and established a deep Southern Ocean pathway for the Antarctic Circumpolar Current (Barker and Burrell, 1977). This, in turn, led to profound changes in climate productivity patterns associated with Antarctic

\footnotetext{
1 Present address: Alfred Wegener Institute for Polar and Marine Research, Postfach 120161, D-27515 Bremerhaven, Germany.

* Corresponding author. Fax: +44-1223-362616.

E-mail address: r.livermore@bas.ac (R.A. Livermore).
}

glaciation (e.g. Diester-Haas and Zahn, 1996). Powell Basin, a small ocean basin off the northernmost Antarctic Peninsula (Fig. 1), centred on $50^{\circ} \mathrm{W}, 62^{\circ} \mathrm{S}$, formed as the South Orkney Microcontinent was rifted from the Antarctic Peninsula (King and Barker, 1988), perhaps synchronous with earliest disruption of the South AmericaAntarctica connection in the Late Eocene. In this case, Powell Basin may have provided a pathway for a 'proto-circumpolar current' (Lawver and Gahagan, 1998). Alternatively, basin opening may have occurred in the Oligocene (e.g. Coren et al., 1997), after initial Drake Passage formation, as a response to east-directed subduction, so that it is, in a sense, a marginal basin. By establishing the opening history of Powell Basin, its role in the 


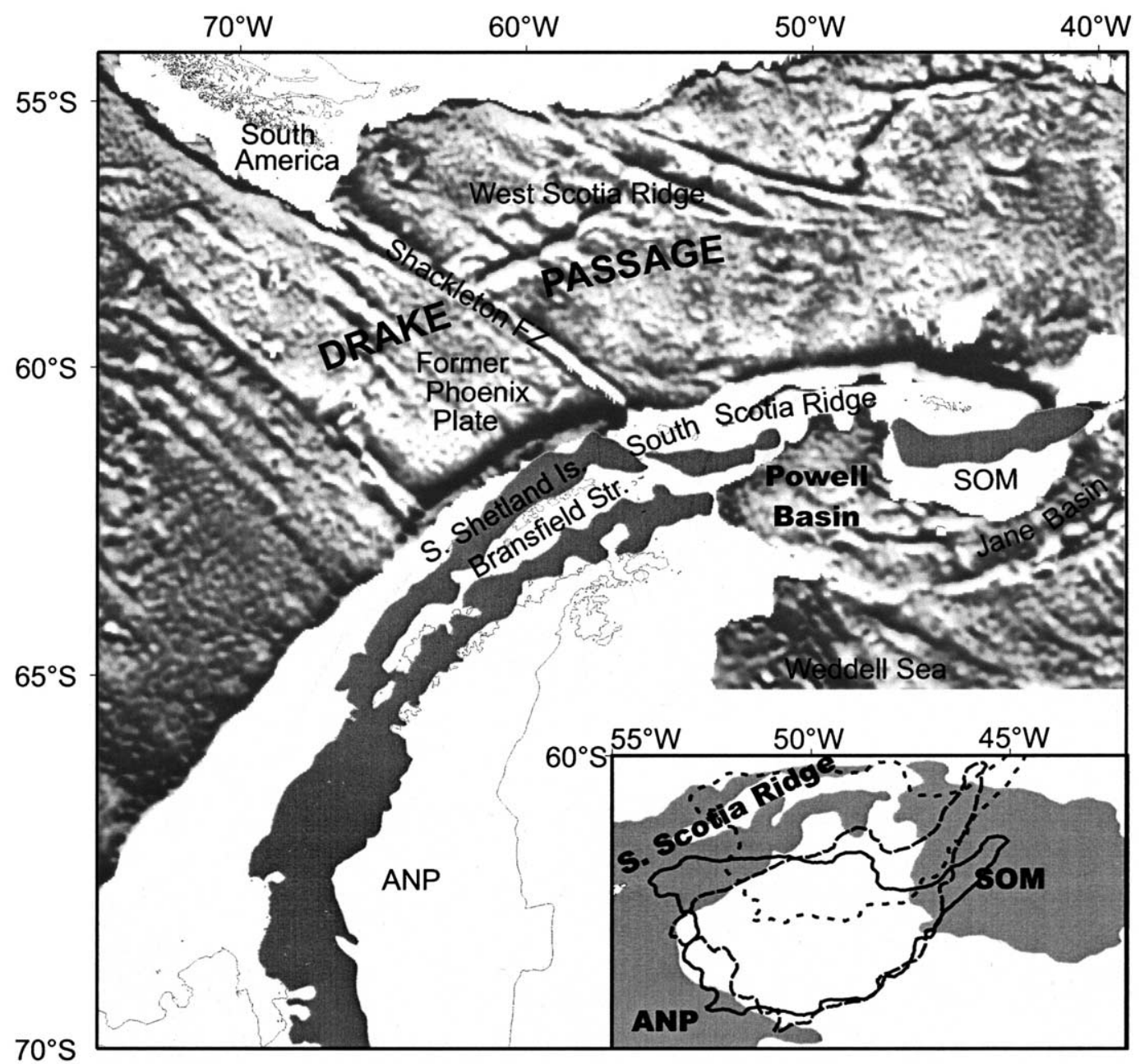

Fig. 1. Location map. Satellite free-air gravity, shown in areas deeper than $2000 \mathrm{~m}$. Dark shading on the Antarctic Peninsula and South Orkney Microcontinent denotes the PMA. Note prominent dextral offset in PMA between the South Shetlands and South Scotia Ridge. Inset shows closure reconstructions; solid: King and Barker, 1988, King et al., 1997 and Maldonado et al., 1998; long dashes: Dalziel, 1984 and Coren et al., 1997; short dashes: Meneilly and Storey, 1986.

formation of a deep water pathway can be assessed more confidently.

The oceanic nature of the basin was established by King et al. (1997) on the basis of seismic reflection and refraction data, but the timing of opening is uncertain, owing to difficulties in interpreting the very low amplitude magnetic anomalies observed there. The South Scotia Ridge lies to the north, while the back-arc Jane Basin lies to the southeast, beyond a series of basement highs, (Lawver et al., 1991; Maldonado et al., 1998). Its eastern and western limits are defined by the mar- gins of the South Orkney Microcontinent and the Antarctic Peninsula respectively, the latter separated from the South Shetland Islands, a little further west, by the active marginal basin of Bransfield Strait. These bounding units together represent a Pacific-facing Mesozoic arc-fore-arc assemblage (e.g. Dalziel and Elliot, 1971, 1973), disrupted by the opening of Powell Basin. Extension in Powell Basin has been dated approximately as lasting from Late Eocene (37 Ma) to Oligocene (23 Ma) using a standard age-depth relationship for oceanic crust (King and Barker, 
1988), but heat flow measurements, corrected for sedimentation, suggest that spreading may have ceased closer to $30.5 \mathrm{Ma}$ (Lawver et al., 1994; Howe et al., 1998).

Dalziel and Elliot (1971) first suggested continuity of the arc-fore-arc terrane through a closed Powell Basin region, and various pre-extension reconstructions have been published since. Dalziel (1984) aligned Mesozoic stretching lineations on South Orkney, South Shetland and Elephant islands. Garrett et al. (1986) reconstructed the signature of the arc terrane on aeromagnetic and marine profiles, and Suriñach et al. (1997) added caveats to fits of this type. However, Meneilly and Storey (1986) question the applicability of fits of structural data having differing ages and uncertain kinematic significance, and so simply extend bathymetric trends with little closure. King and Barker (1988) and King et al. (1997), fitting seismically imaged rift basins on the South Orkney Microcontinent and Antarctic Peninsula, Rodríguez-Fernández et al. (1997), considering sedimentation and basement structure from seismic reflection profiles, and Maldonado et al. (1998), reconsidering much of the data, all produce similar reconstructions (Fig. 1, inset). Coren et al. (1997) identify magnetic spreading anomalies from a marine profile and posit a two-stage post-rift development in Late Oligocene-Miocene and Early Pliocene times. All of these models attempt to explain Powell Basin opening as part of a response to subduction and successive ridge crest-trench collisions at the 'Jane' subduction zone to the south (Barker et al., 1984).

In this paper, gridded magnetic data are used to assess and refine rotations initially derived using the free-air gravity and seismic expression of the Powell rift basins, to produce a model describing a two-stage rift-spreading evolution. For the first time, all the bounding crustal units are incorporated into a self-consistent model presented on a true map projection.

\section{Constraints}

In the absence of reliable magnetic spreading anomalies, the most powerful constraints on Pow- ell Basin's kinematics are from regional satellite free-air gravity maps (e.g. Smith and Sandwell, 1995), together with seismic surveys (e.g. King and Barker, 1988). Free-air gravity lows suggest paired rift basins on the margins of the South Orkney Microcontinent and the Antarctic Peninsula (Fig. 2), an interpretation supported by seismic reflection profiling (King and Barker, 1988).

Within the basin, a gravity low of $\sim 20 \mathrm{mGal}$ amplitude, and strike of approximately $\mathrm{N} 30^{\circ} \mathrm{W}$, marks the extinct rift axis (Fig. 2), and is almost centrally situated, with a slight asymmetry favouring the northeastern flank. Its interpretation as an extinct, buried spreading centre was confirmed by seismic profiling (King et al., 1997). Although this generally has the character of a typical median valley, some profiles reveal the existence of basement highs of limited extent (King et al., 1997), which may represent late-stage eruptions rather like those inferred on segment P2 of the extinct Phoenix Ridge, southwest of the Shackleton Fracture Zone (Livermore et al., 2000). The ridge axis, as defined by the gravity low, is linear, with no large offsets, although a small discontinuity at $62^{\circ} 20^{\prime} \mathrm{S}, 49^{\circ} 50^{\prime} \mathrm{W}$ is evident. South of this, the amplitude of the axial low is reduced to $\sim 10$ mGal, and the width of the basin is much reduced. Coren et al. (1997) have interpreted this region as extended continental crust rather than true oceanic crust.

A major continental magnetic anomaly, the $\mathrm{Pa}$ cific Margin Anomaly (PMA), about $100 \mathrm{~km}$ wide with peak-to-peak amplitudes typically exceeding $1000 \mathrm{nT}$, is thought to represent the Mesozoic arc-batholith in the region, having highs coincident with mafic outcrops on the Antarctic Peninsula (Garrett et al., 1986; Garrett, 1990; Maslanyj et al., 1991). Plutonism within the arc occurred from $\sim 240$ Ma until $10 \mathrm{Ma}$, peaking in the early Cretaceous (142-97 Ma; Leat et al., 1995). In the rift basins, the PMA gives way to 100-200 nT peak-to-peak linear anomalies in crust of transitional nature. Further large amplitude anomalies suggest that the PMA batholith is also present beneath the South Shetland Islands, southern South Scotia Ridge, and the South Orkney Microcontinent (Garrett et al., 1986; Suriñach et al., 1997). 


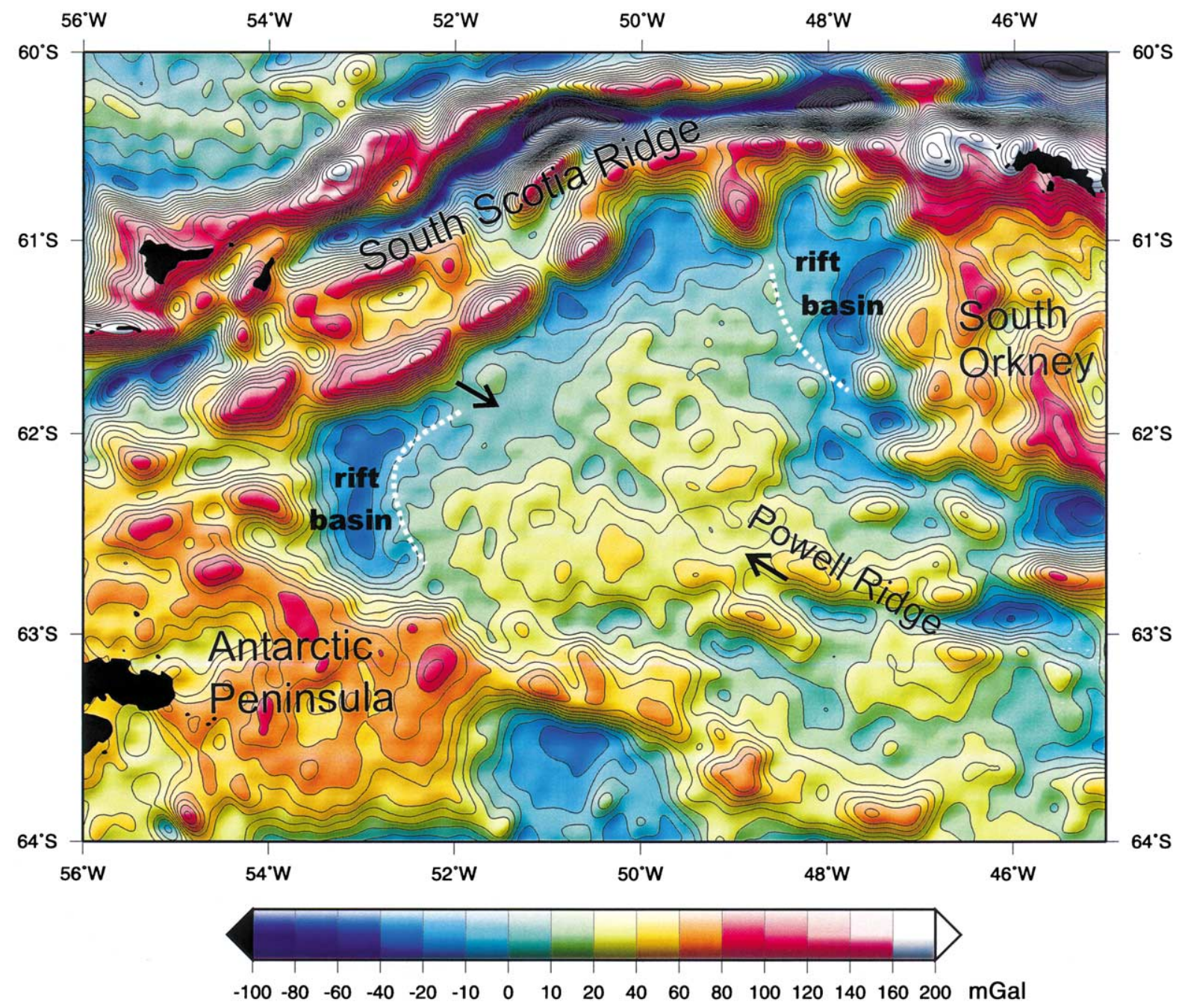

Fig. 2. Free-air gravity anomaly map, using data derived from satellite radar altimetry (Smith and Sandwell, 1995). Note the 10$20 \mathrm{mGal}$ low in the central Powell Basin, marking the extinct Powell Ridge spreading axis.

Previously unpublished USAC aeromagnetic data cover the Powell Basin more densely than existing ship data. A new magnetic anomaly grid, computed from combined aeromagnetic and ship data, reveals the pattern of linear magnetic anomalies for the first time (Fig. 3). As noted previously (e.g. King and Barker, 1988), magnetic anomalies within Powell Basin have low amplitudes (10-40 nT peak-to-peak), which has been attributed to hydrothermal circulation in thick axial sediments of the growing Powell Basin (Levi and Riddihough, 1986; King et al.,
1997). Despite the low amplitudes, careful levelling and surface fitting reveal a pattern of linear magnetic anomalies trending approximately $\mathrm{N} 30^{\circ} \mathrm{W}$, superimposed on longer wavelength, usually negative, regional anomalies. To isolate the anomalies for further analysis, we applied an isotropic bandpass filter, passing wavelengths between $30 \mathrm{~km}$ and $50 \mathrm{~km}$, with taper to $75 \mathrm{~km}$ and $1 \mathrm{~km}$. Since both the axial gravity anomaly and magnetic anomaly peaks on ship profiles trend roughly $\mathrm{N} 30^{\circ} \mathrm{W}$, we felt it appropriate to apply a directional cosine filter with this orienta- 
tion, to maintain linearity in the grid across some of the gaps between profiles. The resulting grid shows a pattern of closely spaced, linear reversals (Fig. 3), that we believe result from seafloor spreading.

From these data, we identify six anomalies (P1-
P6), symmetrically disposed either side of a central complex (P0) of positive and negative anomalies coincident with the free-air gravity trough at the abandoned 'Powell Ridge' spreading centre. The central anomaly complex and gravity freeair trough strike at about $\mathrm{N} 30^{\circ} \mathrm{W}$. Waveforms
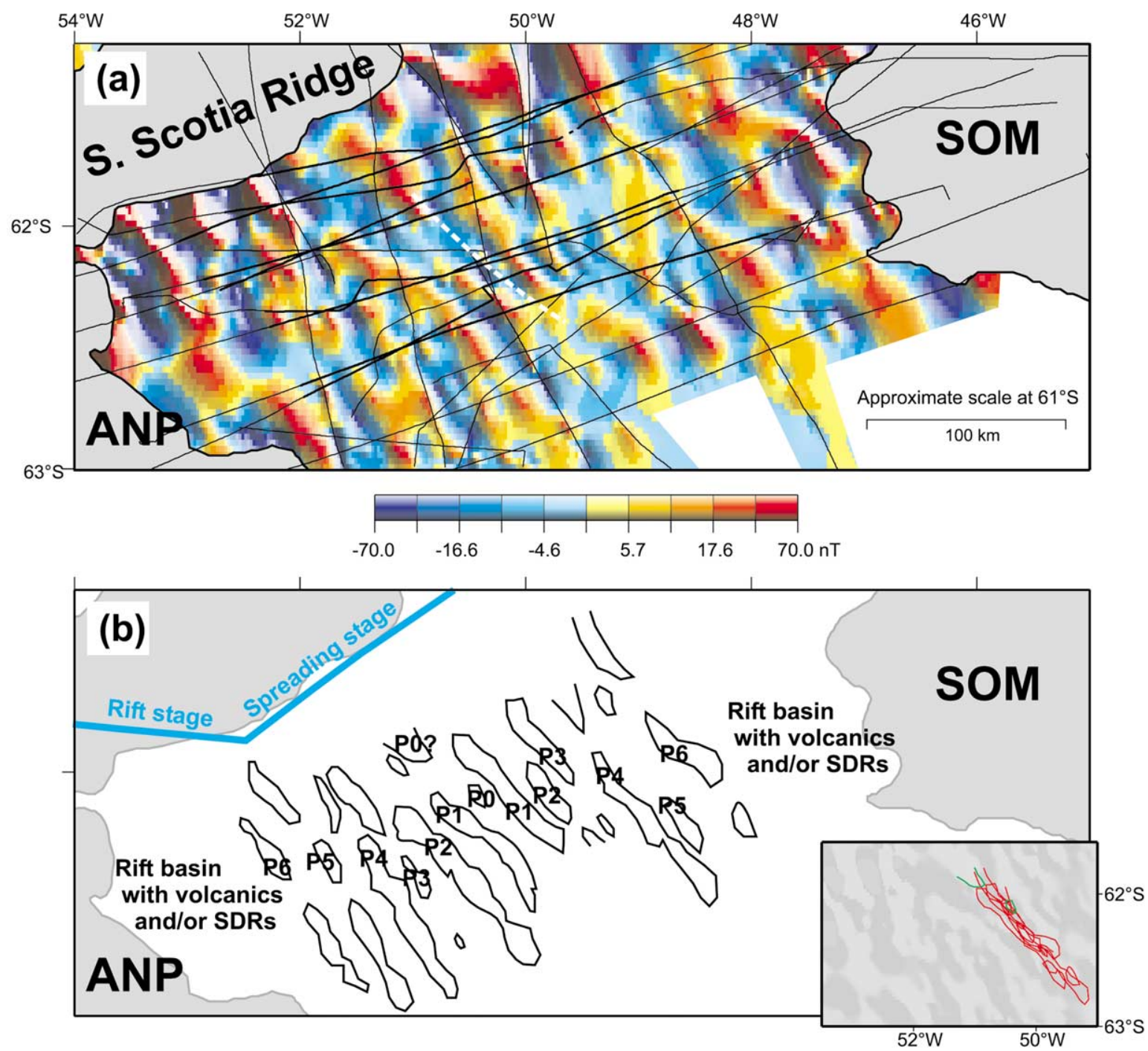

Fig. 3. (a) Gridded airborne and ship magnetic anomaly data in Powell Basin, illuminated from the northeast (for details of processing, see text). Tracks of data used for gridding are shown by thin black lines, slightly thickened for those sections used in Fig. 4. Dotted white line shows the position of the axial gravity trough. (b) Interpretation. P0, the discontinuous central anomaly, and six flanking anomalies (P1-P6) have been identified. Blue line: flowline for the South Orkney Microcontinent during opening of Powell Basin, note its parallelism with the southern edge of the South Scotia Ridge during the spreading stage. Inset, overlain on the anomaly grid (light grey shading) are the half-rotated east flank anomalies (red) and P0 (green). Mercator projections. 


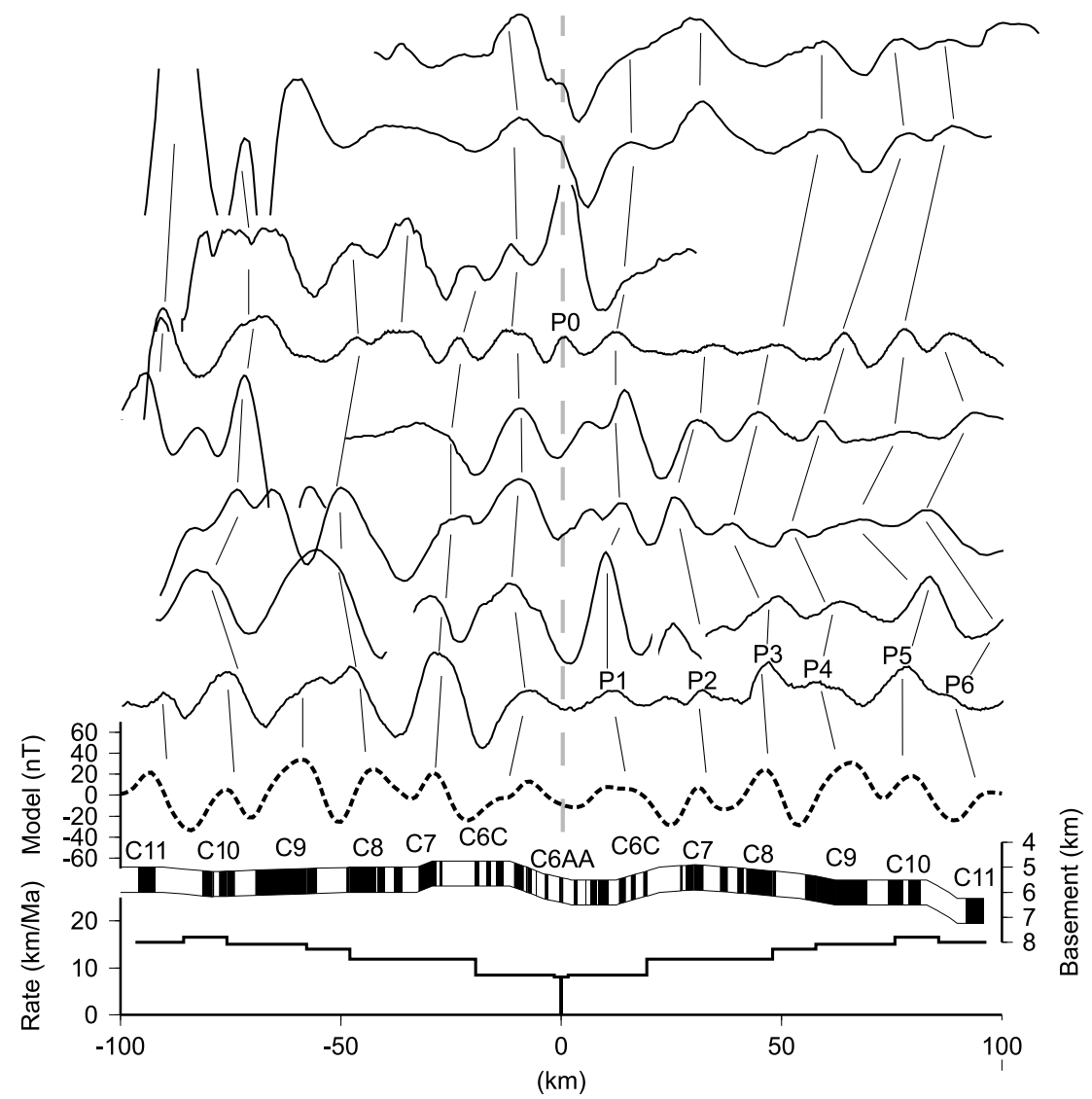

Fig. 4. Eight filtered magnetic and aeromagnetic profiles over Powell Basin (see Fig. 3 for location), projected onto N60 ${ }^{\circ}$ E, and a synthetic profile for spreading 29.8-21.8 Ma (dashed line). Basement depths from Coren et al. (1997). Oceanic layer 2 thickness of $1 \mathrm{~km}$ and effective susceptibility of 0.0016 have been used to model the low amplitude anomalies.

are too poorly developed to be able to establish ages unequivocally, but we present here our favoured model, compared to selected filtered magnetic profiles (Fig. 4). The profiles were projected onto an azimuth of $\mathrm{N} 60^{\circ} \mathrm{E}$, perpendicular to the anomaly strike, in order to compare them with our model spreading anomalies. Using the 2923-Ma interval of King and Barker (1988) as a guide, we obtain a reasonable fit to the profile anomaly peaks P1-P6 with model spreading between $\sim 29.7 \mathrm{Ma}$ (chron C11; Cande and Kent, 1995) and 21.8 Ma (chron C6AA), at slow, declining, spreading rates of $16.5-8 \mathrm{~km} / \mathrm{Ma}$ (Fig. 2). The presence of the central, discontinuous, magnetic high (P0) can be modelled with local extrusion continuing to $\sim 20.5 \mathrm{Ma}$ (C6). With the al- ternative extinction age of $30.5 \mathrm{Ma}$ of Lawver et al. (1994; see also Howe et al., 1998), we modelled six reversals from variable, slow spreading between 43 and 30.6 Ma but with a less satisfactory fit to the peaks. Notwithstanding the low anomaly amplitudes we therefore tentatively adopt the younger age range.

\section{Rotating the South Orkney Microcontinent}

The microplates in the model are defined from satellite free-air gravity, generally following the $15-\mathrm{mGal}$ contour in high gradient areas and with reference to bathymetry. This coincides with the edge of continental crust where seismic 
reflection records are available (e.g. GalindoZaldívar et al., 1996; King et al., 1997). Reconstructions at the beginning and end of rifting were produced by visually fitting the inner and outer margins of the paired rift basins as defined by satellite free-air gravity and seismic reflection profiles (King et al., 1997). The reconstruction produced thus resembles those of King and Barker (1988) and King et al. (1997).

The fit at closure of all these models suffers from overlap between South Orkney and the South Scotia Ridge (Fig. 1). Constraint was introduced using a gridded representation of the PMA (Fig. 3; Morris and Livermore, in preparation). Assuming an originally continuous PMA, we rotate the southern South Scotia Ridge along an offset (Figs. 1 and 5) in the anomaly between the South Scotia Ridge and South Shetland Islands microplates. The South Shetland Islands have been rotated back to fit with the Antarctic Peninsula, representing closure of Bransfield Strait prior to 5.5-3.1 Ma (Larter and Barker, 1991). For this reconstruction, the northern South Scotia Ridge is kept attached to the southern part, dissection of the South Scotia Ridge occurring recently and by very slow relative motion (Pelayo and Wiens, 1989).

To test the spreading phase of our model we rotated each east flank anomaly about a single Euler pole (at $69.7^{\circ} \mathrm{S}, 38.1^{\circ} \mathrm{W}$ ) for rotation of the South Orkney Microcontinent to its presentday location from the end rift reconstruction, by an amount sufficient for a good visual fit with its conjugate to the west. Fig. 3 (inset) shows the anomalies from the east flank after half such a rotation. Each outline fits well with the central anomaly, the gravity trough, and the other east flank anomalies. The small but consistent misfit of the half-rotated anomalies by $\sim 8 \mathrm{~km}$ west of the central anomaly suggests that accretion may have favoured the western flank by $\sim 4 \%$, which is also shown by the widths of crust produced on each flank. A flowline (Fig. 5) for the northwestern South Orkney Microcontinent, derived from the model spreading pole, shows that the modelled spreading direction is (1) orthogonal to the reversal anomalies, (2) parallel to the northern strikeslip margin of Powell Basin and (3) oblique $\left(\sim 20^{\circ}\right)$ to its southern, transtensional, margin (King and Barker, 1988). Hence, this model described by a single pole for rifting and a single pole for spreading at a single ridge - accounts for the distribution of magnetic reversals shown in Powell Basin and for the gross structure of all its margins.

\section{Discussion}

Our model for Powell Basin evolution is illustrated in Fig. 5 by reconstructions of the gridded magnetic anomaly field at closure (40 Ma), endrifting (29.7 Ma), mid-spreading (post-chron C9, $27 \mathrm{Ma})$ and present-day.

\subsection{Closure}

At closure the principal difficulty with our reconstruction is an area of underlap in northwestern Powell Basin which we have eliminated by closure of the Airy, Bouguer, Eötvös and Newton extensional basins within the South Orkney Microcontinent (Fig. 5; King and Barker, 1988). The resultant fragment, shorter in its southern part but unchanged in the north, fills the underlap area comfortably, tightening the fit at closure (assuming an E-W stretching factor of about two, including the Powell rift basin). The Airy, Bouguer and Eötvös basins are thus interpreted as the result of E-W extension of the South Orkney Microcontinent leading to Powell Basin break-up. A major feature of the reconstruction is along-axis dissection of the PMA by western Newton Basin. The PMA is similarly dissected at the South Shetlands, Anvers and Alexander islands on the Antarctic Peninsula, suggesting that it represents a line of crustal weakness along its strike. Newton Basin could be interpreted as a Cretaceous intraor fore-arc basin (following peak PMA activity at $97 \mathrm{Ma}$; Leat et al., 1995) or as a proto-west Scotia Sea extensional feature (50-40 Ma), in the former case having no role in shortening the South Orkney Microcontinent to mitigate underlap at closure.

The cartoon reconstruction of King et al. (1997) (their fig. 16) shows the southern South 

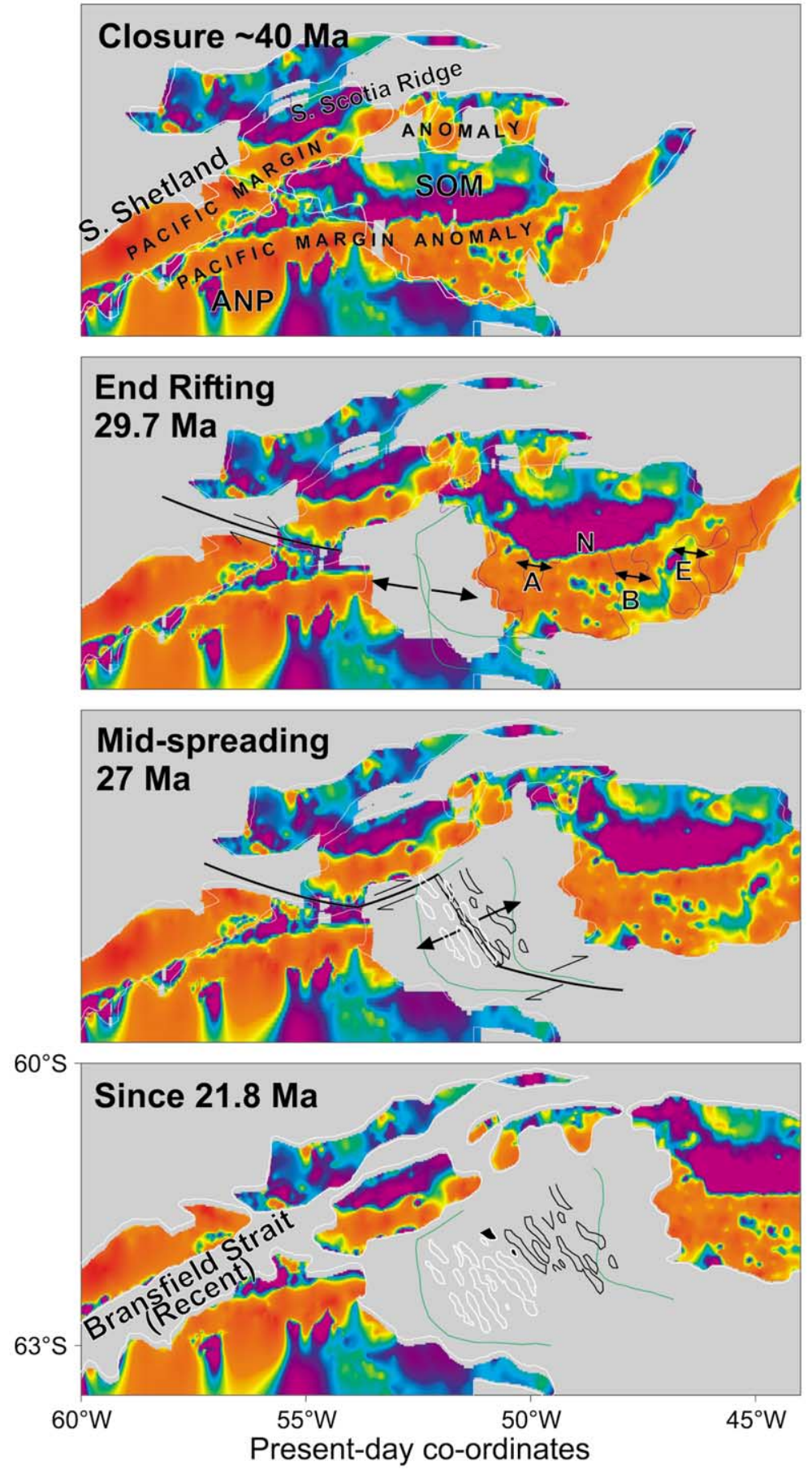

Fig. 5. Reconstructions of regional magnetic anomaly compilation. The closure reconstruction illustrates the South Orkney Microcontinent with extension removed in Airy (A), Bouguer (B), Eötvös (E) and Newton (N) basins, illustrated by dark blue line (45-mGal satellite gravity contour) on end rifting reconstruction. Green lines: King et al.'s (1997) extended continental crust boundary; white outlines: west flank spreading anomalies; black outlines: east flank. Underlap between the southern parts of boundaries of 'extended continental crust' (end-rifting) illustrates transtension along the southern margin of Powell Basin. 
Scotia Ridge placed within our region of underlap to produce a wide, linear, undissected PMA. The advantages of our positioning of the South Scotia Ridge fragments are: (1) movement is along a clear fault-like feature defined in both the gridded magnetic and free-air gravity data which coincide with the block boundaries; (2) it extends the trend and curvature of the PMA from the South Shetland Islands; (3) the southern margin of the South Scotia Ridge acts as the northern strike-slip boundary of Powell Basin; and (4) it does not require compressional tectonism to assemble the modern South Scotia Ridge.

\subsection{Rifting}

The rifting stage of our model is consistent with the definition of the rift basins by seismic and satellite gravity techniques. In view of our magnetic waveform modelling, we assign a possible age of $\sim 40-29.7$ Ma to the rifting process, falling within a period of early extension in the Drake Passage region, postulated on the basis of relative motion of South America and Antarctica (Livermore and Woollett, 1993). The rift basin areas show large negative magnetic anomalies in our grid and there is evidence from seismic reflection records for seaward dipping reflectors in the western (Antarctic Peninsula) rift basin (British Antarctic Survey, unpublished data). These, and evidence from dredges for Eocene-Recent dated alkali basalts in Antarctic Peninsula and South Orkney rift basins (Barber et al., 1991), suggest that break-up volcanism was widespread in the young rift basins.

\subsection{Spreading}

Our model is the first to have been tested with reference to linear magnetic reversal anomalies in Powell Basin. These anomalies are consistent with the model's second stage: monopolar seafloor spreading. In our model of spreading rates, a significant reduction coincides with the first confidently identifiable seafloor spreading in Drake Passage at chron C8 time ( $\sim 26.5 \mathrm{Ma})$, and extinction of Powell Basin occurs just prior to chron C6, a time when South America-Antarctica plate motions underwent rapid change from WNWESE to W-E (Barker and Lawver, 1988; Livermore et al., 1991). These observations are consistent with our suggestion of a close relationship between Powell Basin opening and the early evolution of Drake Passage.

The only previous constraints on spreading were those of King et al. (1997), using short offsets in the axial gravity trough, and Coren et al. (1997), who use a single marine magnetic profile to define a complicated history involving an Early Pliocene stage of spreading only on the eastern flank. Our gridded representation of spreading anomalies does not resemble the fan-shaped area of oceanic crust that this implies, and spreading using the Coren et al. (1997) model fails to predict the peaks evident in our grid.

Furthermore we do not accept the interpretation of Rodríguez-Fernández et al. (1997), involving overlapping spreading centres in Powell Basin, noting that it is not possible to interpret these from the magnetic anomaly grid. We interpret seismic line M12 (their fig. 5) over the essentially continuous axial gravity low to show a buried median valley, more consistent with slow spreading rates, and containing sediments deposited under the influence of bottom currents, consistent with the subdued nature of the magnetic anomalies. This could be taken as evidence for activity of an early stage connection between the Pacific and Atlantic oceans, passing through Powell Basin. Such a suggestion is made by Lawver and Gahagan (1998) in a 32.5-Ma reconstruction showing the Basin acting as an alternative conduit to Drake Passage, which was blocked by continental fragments. This work suggests, in contrast, firstly that Powell Basin would not have been significantly open at oceanic depths until at least 27 Ma and, secondly, that the South Scotia Ridge to the north would have blocked any significant deep circulation from the west, although there remains the possibility of some exchange along the transcurrent fault crossing this margin between the South Shetlands and Elephant Island. We suggest instead that a more likely source for bottom currents in Powell Basin was, as it is today, the Weddell Sea (e.g. Howe et al., 1998). 


\section{Conclusion}

The observed gravity and magnetic features of Powell Basin have been produced by a typical oceanic development episode in miniature. The rifted margins are in continental crust and underwent break-up volcanism before $29.7 \mathrm{Ma}$, when slow oceanic spreading at a single ridge was established. Spreading then continued until extinction at about $21.8 \mathrm{Ma}$. The onset of rifting and extinction of spreading correlate with changes in relative motion between South America and Antarctica, and the creation of Powell Basin is viewed as an integral part of Drake Passage opening. Motions of the South Orkney Microcontinent and the South Scotia Ridge are linked by the concept of a fragmenting connection between South America and Antarctica. We see no reason to invoke the influence of the nearby 'Jane' subduction zone (Barker et al., 1984) to explain extension in Powell Basin as its direct kinematic or dynamic consequence, particularly since a well developed back-arc basin exists at Jane Basin. The role of subduction was incidental in an area already experiencing tension in response to $\mathrm{WNW}_{-}$ ESE plate motion as the tips of South America and the Antarctic Peninsula separated after a long period of connection (Livermore and Woollett, 1993). We believe it likely that bottom water circulation in the basin since its opening has been sourced from the Weddell Sea, although the basin could also have acted as a conduit for a limited circum-Antarctic flow.

\section{Acknowledgements}

This work was funded by NERC Award GT22/ 95/ANT4/3, made under the Antarctic Special Topic. We acknowledge Peter Morris of BAS for his help with gridded data. Derek Fairhead (GETECH/Leeds), Joe Cann (Leeds) and Ed King (BAS) provided helpful discussions and comments. Franco Coren and Andres Maldonado are thanked for their constructive reviews of the manuscript. Figures were drafted making use of the Generic Mapping Tools (GMT).

\section{References}

Barber, P.L., Barker, P.F., Pankhurst, R.J., 1991. Dredged rocks from Powell Basin and the South Orkney Microcontinent. In: Thomson, M.R.A., Crame, J.A., Thomson, J.W. (Eds.), Geological Evolution of Antarctica. Cambridge University Press, Cambridge, pp. 361-367.

Barker, P.F., Burrell, J., 1977. The opening of the Drake Passage. Mar. Geol. 25, 15-34.

Barker, P.F., Barber, P.L., King, E.C., 1984. An early Miocene ridge crest - trench collision on the South Scotia Ridge near $36^{\circ} \mathrm{W}$. Tectonophysics 102, 315-332.

Barker, P.F., Lawver, L.A., 1988. South American-Antarctic plate motion over the past $50 \mathrm{My}$, and the evolution of the South American - Antarctic Ridge. Geophys. J. 94, 377385.

Cande, S.C., Kent, D.V., 1995. Revised calibration of the geomagnetic polarity time scale for the late Cretaceous and Cenozoic. J. Geophys. Res. 100, 6093-6095.

Coren, F., Ceccone, G., Lodolo, E., Zanolla, C., Zitellini, N., Bonazzi, C., Centonze, J., 1997. Morphology, seismic structure and tectonic development of the Powell Basin, Antarctica. J. Geol. Soc. London 154, 849-862.

Dalziel, I.W.D., 1984. Tectonic evolution of a fore-arc terrane, southern Scotia Ridge, Antarctica. Geol. Soc. Am. Spec. Publ. 200, 1-32.

Dalziel, I.W.D., Elliot, D.H., 1971. Evolution of the Scotia Arc. Nature 233, 246-251.

Dalziel, I.W.D., Elliot, D.H., 1973. The Scotia Arc and Antarctic margin. In: Nairn, A.E.M., Stehli, D.H. (Eds.), The Ocean Basins and Margins, 1, The South Atlantic. Plenum Press, New York, pp. 171-245

Diester-Haas, L., Zahn, R., 1996. Eocene-Oligocene transition in the Southern Ocean: history of water mass circulation and biological productivity. Geology 24, 163-166.

Galindo-Zaldívar, J., Jabaloy, A., Maldonado, A., Sanz de Galdeano, C., 1996. Continental fragmentation along the South Scotia Ridge transcurrent plate boundary (NE Antarctic Peninsula). Tectonophysics 258, 275-301.

Garrett, S.W., Renner, R.G.B., Jones, J., McGibbon, K.J., 1986. Continental magnetic anomalies and the evolution of the Scotia Arc. Earth Planet. Sci. Lett. 81, 273-281.

Garrett, S.W., 1990. Interpretation of reconnaissance gravity and aeromagnetic studies of the Antarctic Peninsula. J. Geophys. Res. 95, 6759-6777.

Howe, J.A., Livermore, R.A., Maldonado, A., 1998. Mudwave activity and current-controlled sedimentation in Powell Basin, northern Weddell Sea, Antarctica. Mar. Geol. 149, 229241.

King, E.C., Barker, P.F., 1988. The margins of the South Orkney Microcontinent. J. Geol. Soc. London 145, $317-$ 331.

King, E.C., Leitchenkov, G., Galindo-Zaldívar, J., Maldonado, A., Lodolo, E., 1997. Crustal structure and sedimentation in Powell Basin. In: Barker, P.F., Cooper, A.K. (Eds.), Geology and Stratigraphy of the Antarctic Margin Part 2. 
Antarctic Research Series, vol. 71. AGU, Washington, DC, pp. $75-93$

Larter, R.D., Barker, P.F., 1991. Effects of ridge crest-trench interaction on Antarctic-Phoenix spreading: forces on a young subducting plate. J. Geophys. Res. 96, 1958319607

Lawver, L.A., Gahagan, L.M., 1998. Opening of Drake Passage and its impact on Cenozoic ocean circulation. In: Crowley, T.J., Burke, K.C. (Eds.), Tectonic Boundary Conditions for Climate Reconstructions. Oxford University Press, Oxford, pp. 212-223

Lawver, L.A., Della Vedova, B., Von Herzen, R.P., 1991. Heat flow in Jane Basin, Northwest Weddell Sea. J. Geophys. Res. 96, 2019-2038.

Lawver, L.A., Williams, T., Sloan, B., 1994. Seismic stratigraphy and heat flow of Powell Basin. Terr. Antarct. 1, 309310.

Leat, P.T., Scarrow, J.H., Millar, I.L., 1995. On the Antarctic Peninsula batholith. Geol. Mag. 132, 399-412.

Levi, S., Riddihough, R., 1986. Why are marine magnetic anomalies suppressed over sedimented spreading centres? Geology 14, 651-654.

Livermore, R.A., Woollett, R.W., 1993. Seafloor spreading in the Weddell Sea and southwest Atlantic since the Late Cretaceous. Earth Planet. Sci. Lett. 117, 475-495.

Livermore, R.A., Tomlinson, J.S., Woollett, R.W., 1991. Unusual sea-floor fabric near the Bullard fracture zone imaged by GLORIA sidescan sonar. Nature 353, 158-161.

Livermore, R.A. et al., 2000. Autopsy on a dead spreading centre: the Phoenix Ridge, Drake Passage, Antarctica. Geology 28, 607-610.

Maldonado, A., Zitellini, N., Leitchenkov, G., Balanyá, J.C., Coren, F., Galindo-Zaldívar, J., Lodolo, E., Jabaloy, A., Zanolla, C., Rodríguez-Fernández, J., Vinnikovskaya, O., 1998. Small ocean basin development along the Scotia-Antarctica plate boundary and in the northern Weddell Sea. Tectonophysics 296, 371-402.

Maslanyj, M.P., Garrett, S.W., Johnson, A.C., Renner, R.G.B., Smith, A.M., 1991. Aeromagnetic anomaly map of West Antarctica (Weddell Sea sector). BAS Geomap Series, Sheet 2, Cambridge, $34 \mathrm{pp}$.

Meneilly, A.W., Storey, B.C., 1986. Ductile thrusting within subduction complex rocks on Signy Island, South Orkney Islands. J. Struct. Geol. 8, 457-472.

Pelayo, A.M., Wiens, D.A., 1989. Seismotectonics and relative plate motions in the Scotia Sea region. J. Geophys. Res. 94, 7293-7320.

Rodríguez-Fernández, J., Balanyá, J.C., Galindo-Zaldívar, J., Maldonado, A., 1997. Tectonic evolution and growth patterns of a restricted ocean basin: the Powell Basin (Northeastern Antarctic Peninsula). Geodin. Acta 10, 159-174.

Smith, W.H.F., Sandwell, D.T., 1995. Marine gravity field from declassified Geosat and ERS-1 altimetry. EOS Trans. Am. Geophys. Union 76, 156.

Suriñach, E., Galindo-Zaldívar, J., Maldonado, A., Livermore, R.A., 1997. Large amplitude magnetic anomalies in the northern sector of the Powell Basin, NE Antarctic Peninsula. Mar. Geophys. Res. 19, 65-80. 